\title{
Disaster preparedness of the selected Barangays in Rizal, Nueva Ecija
}

\section{Clara J. Carpio}

Nueva Ecija University of Science and Technology, Philippines

clarajcarpio@yahoo.com

\begin{abstract}
Despite substantial public danger awareness commitment and spending, rates of preparedness for disasters remain low. The study used the descriptive method of research. It was found that the disaster preparedness programs and activities on the selected Barangays in Rizal, Nueva Ecija are effective however, it needs improvement on the implementation of the programs so that it will be more effective. The result on the problems about the implementation ofdisaster preparedness programs and activities is disgracing because those programs and activities have only one aim: to help the community. Local government may generate everyone awareness on the difficulties of implementing disaster preparedness activities and programs. Also, the barangay may conduct trainings or seminars for the barangay officials about disaster preparedness.
\end{abstract}

Keywords-Disaster, Preparedness, Disaster Management, Barangay, Disaster Preparedness.

\section{INTRODUCTION}

Despite substantial public danger awareness commitment and spending, rates of preparedness for disasters remain low. As viewed by Collin (2000), Disasters take different forms, ranging from natural disasters, such as tornadoes, to manmade disasters, such as incidents of violence in the workplace, and occur far too often. Dekens (2007) stated that it is only recently that real attention has begun to be given to the value of incorporating local knowledge and traditions into construction and environmental programs, but the approach is still far from becoming commonplace.

Kirschenbaum (2002) concluded that management practices aimed at increasing disaster preparedness behaviors must focus on those variables that directly affect each type of preparedness construct separately. Kohn et al. (2012) also concluded that factors affecting preparedness attitudes and behaviors are complex and multifaceted, including demographic characteristics, trust in government efforts, prior catastrophe experience, and the number of household dependents.

Evidenced in the study of Center (2006), concluded that the awareness of the people about the importance of vegetation to protect the environment from landslides is important to indirectly reduce the rate of deforestation and thus enable the population to prevent landslide disasters.

In view of the foregoing insights about dis aster preparedness, the researcher had the interest in assessing the disaster preparedness of the selected barangays in Rizal, Nueva Ecija . In this study, the officials of the municipality will be more disaster-prepared that will prevent major damages and casualties to its jurisdiction.

\section{CONCEPTUAL FRAMEWORK}

Measuring the degree of vulnerability and preparedness of the population as well as realistic awareness and stakeholder understanding of the extent to which preparedness measures should be taken to reduce the risk of dis asters in high risk areas is particularly important. (Hidayati, 2012)

This study is mainly anchored on the study of Luna (2000) that stated the nature and extent of government collaboration in disaster preparedness and mitigation issues varies widely depending on their roots, either in past confrontations and political struggles or traditional charitable activities. Supported by Allen (2006), Community-based solutions to disaster preparedness (CBDP) are increasingly important components of policies to mitigate risk and handle disasters.

\section{OBJECTIVE OF THE STUDY}

The study described the the level of effectiveness of the different programs or activities implemented by the government for disaster preparedness, and problems encountered in the implementation of programs and activities for disaster preparedness in the barangay. 


\section{METHODOLOGY}

The study used the descriptive method of research. The Descriptive analysis method is beyond data collection and tabulation. This includes the description elements with the context of what is defined. Thus, description is often combined with the measurement, classification, interpretation, and evaluation of comparison and contrast. (Willis et al., 2016)

\section{RESULTS}

Table 1 showed that the statement "House to house briefing" obtained the highest weighted mean of (3.22) with a verbal interpretation of "Effective" while statements "Disaster coordination and calamity", "Barangay training and seminars on disaster preparedness", and "Educational Services and Moral Recovery Program" obtained the lowest weighted mean of (2.78) with a verbal interpretation of "Effective".

Table 1. Effectiveness of Disaster Preparedness Programs and Activities

\begin{tabular}{|l|c|c|}
\hline DISASTER PREPAREDNESS PROGRAMS AND ACTIVITIES & Weighted Mean & Verbal Interpretation \\
\hline 1.House to house briefing & 3.22 & Effective \\
\hline 2. Conducting of Emergency drills & 3.20 & Effective \\
\hline 3. Rescue Training. & 3.10 & Effective \\
\hline 4.Training for Senior Citizen and Women in emergency situation & 3.10 & Effective \\
\hline 5. Basic Life Support Training,. & 3.08 & Effective \\
\hline 6.Construction of Multi-Purpose Hall for evacuation & 3.20 & Effective \\
\hline 7.Green Brigade & 2.99 & Effective \\
\hline 8 Disaster Coordination and Calamity & 2.78 & Effective \\
\hline 9 Barangay Training and Seminars on Disaster Preparedness & 2.78 & Effective \\
\hline 10 Educational Services \& Moral Recovery Program & 2.78 & Effective \\
\hline 11. Livelihood Program & 2.89 & Effective \\
\hline 12.Early preparation of relief goods & 2.94 & Effective \\
\hline Total Weighted Mean & 3.00 & Effective \\
\hline
\end{tabular}

Table 2 showed that the statement "Lack of interest of the community regarding the preparedness programs initiated" gained the highest weighted mean of (3.22) with a verbal interpretation of "Serious" while statement "Lack of qualified individuals to c onduct trainings" gained the lowest weighted mean of (2.69) with a verbal interpretation of "Serious".

Table 2. Problems encountered in the implementation of the programs in the community.

\begin{tabular}{|l|c|c|}
\hline \multicolumn{1}{|c|}{} & $\begin{array}{c}\text { Weighted } \\
\text { Mean }\end{array}$ & Verbal Interpretation \\
\hline $\begin{array}{l}\text { 1. Lack of information dissemination efforts of the barangay } \\
\text { obout the incoming disaster }\end{array}$ & 3.20 & Serious \\
\hline $\begin{array}{l}\text { 2. Lack of interest of the community regarding the preparedness } \\
\text { programs initiated. }\end{array}$ & 3.22 & Serious \\
\hline 3. Lack of communication between community and the official & 3.04 & Serious \\
\hline 4 Lack of equipment or materials & 3.00 & Serious \\
\hline $\begin{array}{l}\text { 5.Lack of budget of the barangay or LGU's in giving relief } \\
\text { goods }\end{array}$ & 3.07 & Serious \\
\hline 6.Lack of qualified individuals to conduct trainings & 2.69 & Serious \\
\hline $\begin{array}{l}\text { 7. Absence of the members of the community during } \\
\text { information drives }\end{array}$ & 3.16 & Serious \\
\hline 8.Lack of Involvement of the barangay official s & 2.79 & Serious \\
\hline 9.Non-cooperation of the community & 3.10 & Serious \\
\hline 10 Improper information given by the officials. & 2.74 & Serious \\
\hline Total Weighted Mean & 3.00 & Serious \\
\hline
\end{tabular}




\section{CONCLUSION AND DISCUSSION}

The disaster preparedness programs and activities on the selected Barangays in Rizal, Nueva Ecija are effective however, it needs improvement on the implementation of the programs so that it will be more effective. The community may support the projects that can be helpful for the community by participating in every activity provided by the barangay.

The result on the problems about the implementation of disaster preparedness programs and activities is disgracing because those programs and activities have only one aim: to help the community. Local government may generate everyone awareness on the difficulties of implementing disaster preparedness activities and programs. Also, the barangay may conduct trainings or seminars for the barangay officials about disaster preparedness.

\section{REFERENCES}

[1] Allen, K. M. (2006). Community-based disaster preparedness and climate adaptation: local capacity-building in the Philippines. Disasters, 30(1), 81-101.

[2] Center, A. D. P. (2005). Total disaster risk management: Good practices. Asian Disaster Preparedness Center (ADPC).

[3] Collins, L. R. (2000). Disaster management and preparedness. CRC Press.

[4] Dekens, J. (2007). Local knowledge for disaster preparedness: A literature review. International Centre for Integrated Mountain Development (ICIM OD).

[5] Hiday ati, D. (2012). Striving to reduce disaster risk: Vulnerable communities with low levels of preparedness in Indonesia. Journal of Disaster Research, 7(1), 2012.

[6] Kirschenbaum, A. (2002). Disaster preparedness: A conceptual and empirical reevaluation. International Journal of Mass Emergencies and Disasters, 20(1), 5-28.

[7] Kohn, S., Eaton, J. L., Feroz, S., Bainbridge, A. A., Hoolachan, J., \& Barnett, D. J. (2012). Personal disaster preparedness: an integrative review of the literature. Disaster medicine and public health preparedness, 6(3), 217-231.

[8] Luna, E. M. (2001). Disaster mitigation and preparedness: the case of NGOs in the Philippines. Disasters, 25(3), 216-226.

[9] Willis, D. G., Sullivan-Boly ai, S., Knafl, K., \& Cohen, M. Z. (2016). Distinguishing features and similarities between descriptive phenomenological and qualitative description research. Western journal of nursing research, 38(9), 11851204. 